\title{
In Vitro Antimicrobial Activity and Fungitoxicity of Syringic Acid, Caffeic Acid and 4-hydroxybenzoic Acid against Ganoderma Boninense
}

\author{
Khim Phin Chong (Corresponding author) \\ School of Sustainable Agriculture, Universiti Malaysia Sabah \\ Locked Bag 2073, 88999 Kota Kinabalu, Sabah, Malaysia \\ Tel: 60-8-8320-000 x5655 E-mail: chongkp@ums.edu.my \\ Stephen Rossall \\ Plant and Crop Sciences, Sutton Bonington Campus, University of Nottingham \\ Loughborough, LE12 5RD, United Kingdom \\ Tel: 44-0115-951-6338_E-mail: stephen.rossall@nottingham.ac.uk \\ Markus Atong \\ School of Sustainable Agriculture, Universiti Malaysia Sabah \\ Locked Bag 2073, 88999 Kota Kinabalu, Sabah, Malaysia \\ Tel: 60-8-8320-306 E-mail: xabex96@ums.edu.my
}

\begin{abstract}
This paper discusses the in vitro antimicrobial activity and fungitoxicity of syringic acid, caffeic acid and 4-hydroxybenzoic acid which is found in oil palm root. Experiments were observed for fourteen days, repeated at least three times and data were recorded daily. The antimicrobial activities and fungitoxicity of the phenolics against Ganoderma boninense were expressed in inhibition of radial growth of $G$. boninense on PDA ameliorated with the three different phenolics with a range concentration of $0.5-2.5 \mathrm{mg} / \mathrm{ml}$. Syringic acid was found to be very fungitoxic to $G$. boninense even at concentration of $0.5 \mathrm{mg} / \mathrm{ml}$, the lowest concentration tested in this experiment. When the concentration is increase to $1.0 \mathrm{mg} / \mathrm{ml}$ of syringic acid, the pathogen is inhibited. Caffeic acid and 4-hydroxybenzoic acid were having inhibitory effect with the highest concentration tested; $2.5 \mathrm{mg} / \mathrm{ml}$ strongly inhibited the growth of $G$. boninense in comparison to the control.
\end{abstract}

Keywords: Ganoderma boninense, Syringic acid, Caffeic acid, 4-hydroxybenzoic acid

\section{Introduction}

Oil palm (Elaies guineensis Jacq.) is truly "a golden crop of Malaysia” since it generates profitable export earning for the country and truly nature's gifts for alleviating poverty in Malaysia (Basiron, 2007). The Malaysian palm oil industry is economically big and diversified. Malaysia is currently the world's largest producer and exporter of oil palm. Areas of oil palm have increased from 54,000 hectares in 1960 to 4.05 million hectares in 2005, reflecting a compound annual growth of $10.06 \%$. Production increased from 94,000 tones in 1960 to 15 million tones in 2005 , or almost 160 times within 45 years. This represents a compound annual growth of 11.93\% per year (Basiron, 2007). The devastating Basal Stem Rot (BSR) disease caused by Ganoderma boninense is considered the most serious disease faced by oil palm in Malaysia (Benjamin, 1995). Oil palm has an economic life span of 25-30 years. Basal stem rot can kill more than 80 percent of stands by the time they are half-way through normal economic life (Abdul Razak et al., 2004). In the late 1960s and early 1970s in Sumatra, there was little decline in the yield of oil palm until the surviving stand had fallen to about $115 \mathrm{palm} / \mathrm{ha}$, but in more recent plantings, any loss of palm was associated with a loss of yield (Corley and Tinker, 2003). Yield of infected palms was also reduced by $20-40 \%$ compared to the year before infection was detected (Khairudin, 1995). Palms with Ganoderma yielded between 13 and 21\% less than healthy palms at the same age 
(Nazeeb et. al., 2000). Heavily infected field yielded $26 \%$ less at 11 years after planting, and $46 \%$ less at 15 years by which time incidence was 67\% (Gurmit, 1991). There is currently no effective cure for G. boninense infection in an existing stand. Preventive and ameliorative treatments which are commonly carried out show various degrees of effectiveness (Sariah and Zakaria, 2000). Determination of total phenolic content in G. boninense infected and healthy oil palm roots showed susceptible palm roots at week four had low phenolic content, whereas week one had high phenolic content. Gallic acids concentrations decreased in the four weeks old roots of infected susceptible palms compared to healthy roots. Determination of total phenolic content in infected palm seedlings root (DX P) also showed low phenolic content compared to the non infected palm seedlings root. This indicate phenolic compounds are involved in oil palm resistance against Ganoderma (Mohamad Arif et. al., 2007).To identify the possibility of oil palm resistance against $G$. boninense in certain circumstances need further investigation. However, if resistance in oil palm against $G$. boninense is possible, it may contribute to tackling the problem. In a collaborative experiment to this research, we have also found syringic acid, caffeic acid and 4-hydroxybenzoic acid present in oil palm roots in natural condition or after elicitation. In this paper, we present the works on in vitro effect of syringic acid, caffeic acid and 4-hydroxybenzoic acid to G. boninense.

\section{Materials and methods}

\subsection{Ganoderma boninense}

Cultures were provided by Borneo Samudera Sdn Bhd, Sabah, Malaysia, maintained at $25^{\circ} \mathrm{C}$ on Potato Dextrose Agar (PDA).

\subsection{In vitro bioassay}

A series of $0,0.5,1.0,1.5,2.0$ and $2.5 \mathrm{mg} / \mathrm{ml}$ of syringic acid, caffeic acid and 4-hydroxybenzoic acid from Sigma $\mathbb{R}$ were ameliorated into the PDA, which the phenolics were first dissolved in Acetone: Water $(50: 50 ; \mathrm{v} / \mathrm{v})$. Solvent was served as positive control. The growth of the pathogen was expressed in centimeter of radial growth.

\section{Results and discussion}

\subsection{In Vitro bioassays}

In vitro bioassays were conducted to test the fungitoxicity and antimicrobial activities of syringic acid, caffeic acid and 4-hydroxybenzoic acid to G. boninense. Syringic acid was found to be very toxic to G. boninense. Although at the lowest concentration tested $(0.5 \mathrm{mg} / \mathrm{ml}), G$. boninense was fully inhibited up to day 5 . There was slight non significant increase in the diameter measured of the pathogen at day 6 up to day 15 (Figure 1). Higher concentrations of syringic acid tested $(1.0,1.5,2.0$ and $2.5 \mathrm{mg} / \mathrm{ml}$ ) totally stopped the growth of the pathogen (Figure 2, 3, 4, 5 \& 6). Growths of $G$. boninense both in positive and negative control were not significant to each other indicate the toxicity was coming from the phenolic and not from the solvent. Maximum growths $(9 \mathrm{~cm})$ were achieved by both positive and negative control within 10 days after incubation. This is in correlation to many works on plants which demonstrated the fungitoxicity effect of syringic acid. In resistance raspberry to fungus Didymella, syringic acid was found accumulated in the bordering zone of lesion forming a barrier to the fungus. The in vitro fungitoxic of syringic acid was later confirmed to be very toxic at low concentration (Kozlowska and Krzywanski, 1994). In sugar cane, cultivar Mayarí 55-14, which is highly resistant to smut disease showed a major accumulation pattern of syringic acid when interact with the pathogen (de Armas et. al., 2007).

In another hand, pathogen inoculated into agar containing $0.5 \mathrm{mg} / \mathrm{ml}$ of caffeic acid and 4-hydroxybenzoic acid showed a significantly increased throughout the observation, to a maximum size of the plate at day 11. Surprisingly, in 1.0 $\mathrm{mg} / \mathrm{ml}$ and $1.5 \mathrm{ml} / \mathrm{mg}$ of caffeic acid and 4-hydroxybenzoic acid the growth of this pathogen is greater than control and reached a maximum at day 10 (for 4-hydroxybenzoic acid), but grow slower in 1.0 and $1.5 \mathrm{mg} / \mathrm{ml}$ of caffeic acid after day 10 in comparison to control. Both caffeic acid and 4-hydroxybenzoic acid failed to fully inhibit G. boninense when the concentration was raised up to $2.0 \mathrm{mg} / \mathrm{ml}$. But the pathogen managed only to grow up to $5.58 \mathrm{~cm}$ (in 4-hydroxybenzoic acid) and $6.57 \mathrm{~cm}$ (in caffeic acid) at last day of observation.

But the effect of 4-hydroxybenzoic acid was obviously inhibitory with the highest concentration tested in this experiment $(2.5 \mathrm{mg} / \mathrm{ml})$ which caused the $G$. boninense reached only $3.28 \mathrm{~cm}$ in diameter after 14 days. If this concentration is achievable in oil palm root, 4-hydroxybenzoic acid may play a role in the real G. boninense-root interaction. The role of this phenolic has been demonstrated in rice hull against various microorganisms. An evaluation of $50 \%$ inhibition of growth $\left(\mathrm{IC}_{50}\right)$ revealed that most of the gram-positive and some gram-negative bacteria were sensitive to 4-hydroxybenzoic acid at $\mathrm{IC}_{50}$ concentrations of 100-170 $\mu \mathrm{g} / \mathrm{ml}$ (Cho, et. al., 1998). But in caffeic acid the growth of this pathogen continuously to increase significantly after day 6 although in the same concentration as 4-hydroxybenzoic acid, gave a maximum growth of $7.68 \mathrm{~cm}$ at day 14 . But the growth rate of this pathogen was inhibited by this concentration in comparison to control. This is in accordance to many research that showed caffeic acid is ubiquitously present in plants and a potent phytotoxin affecting plant growth and their physiology (Singh et. al., 2009). In another report, caffeic acid was also found inhibiting the growth of four sweet potato pathogenic fungi and 
germination of proso millet seeds in bioassays. Inhibitory activity in the bioassays reported also suggests high periderm caffeic acid levels contribute to the storage root defense chemistry of some sweet potato genotypes (Harisson et. al., 2003).

\section{Conclusion}

In this paper, we presented the result of in vitro experimental investigation on the antimicrobial activity and fungitoxicity of syringic acid, caffeic acid and 4-hydroxybenzoic acid to G. boninense inoculated on PDB ameliorated with different concentration of the phenolics respectively. We found syringic acid is the most fungitoxic phenolic among the three, with the lowest tested concentration; $0.5 \mathrm{mg} / \mathrm{ml}$ can inhibit the growth of G. boninense while $1.0 \mathrm{mg} / \mathrm{ml}$ totally killed the pathogen. On another hand, the highest tested concentration of caffeic acid and 4-hydroxybenzoic acid; 2.5 $\mathrm{mg} / \mathrm{ml}$ only inhibited the growth of $G$. boninense in comparison to the control.

\section{Acknowledgments}

The authors wish to extend their highest appreciation to Prof. Dr. Ridzwan Abd Rahman, the Dean, School of Sustainable Agriculture, Universiti Malaysia Sabah for his for supports and advices throughout the study. We acknowledged the support from Ministry of Science, Technology and Innovation, Malaysia for funding the research through e-Science Fund 0026 and Borneo Samudera Sdn Bhd for supply of seedlings. Last but not least, to Mr. Collin G. Joseph for giving comments on this article.

\section{References}

Abdul Razak, J., Ahmad, H., Ramdhan, K., Idris, A.S., Abdul Rahim, S., Aminul, R. \& Fauzi, I. (2004). Mechanical trunk injection for control of Ganoderma. MPOB Information Series. MPOB TT No. 215.

Basiron, Y. (2007). Palm oil production through sustainable plantations. European Journal of Lipid Science and Technology, 109:289-295.

Benjamin, M., \& Chee, K.H. (1995). Basal stem rot of oil palm-a serious problem on inland soils. MAPPS Newsletter, 19(1):3.

Cho, J.Y., Moon, J.H., Seong, K.Y., \& Park, K.H. (1998). Antimicrobial activity of 4-hydroxybenzoic acid and trans 4-hydroxycinnamic acid isolated and identified from rice hull. Bioscience, biotechnology, and biochemistry, 62:2273-2276.

Corley, R.H.V. \& Tinker, P.B. (2003). The Oil Palm. $4^{\text {th }}$ Edition. Blackwell Publishing. Great Britain. pp.27-28, 407-413.

de Armas R., Santiago, R., Legaz, M.E., \& Vicente, C. (2007). Levels of phenolic compounds and enzyme activity can be used to screen for resistance of sugarcane to smut (Ustilago scitaminea). Australasian Plant Pathology, 36(1):32-38.

Gurmit, S. (1991). Ganoderma-the scourge of oil palms in the coastal areas. The Planter, 67:421-444

Khairudin, H. (1995). Basal stem rot of oil palm caused by Ganoderma boninense: An update. In: Proceedings 1993 PORIM International Palm Oil Congress-Agriculture. Palm Oil Research Institute, Kuala Lumpur, Malaysia. pg. 739-749.

Harrison, H.F., Peterson, J.K., Snook., M.E., Bohac, J.R., \& Jackson, D.M. (2003). Quantity and potential biological activity of caffeic acid in sweet potato [Ipomoea batatas (L.) Lam.] storage root periderm. Journal of Agricultural and food Chemistry, 51(10):2943-2948.

Kozlowska, M., \& Krzywanski, Z. (1994). The possible role of phenolic compounds in red raspberry resistance to Didymella applanata (Niessl) Sacc. Acta Horticulturae, 381:671-674.

Mohamad Arif, A.M., Abrizah, O., Zetty Norhana, B.Y., Syahanim, S., Idris, A.S., Mohd Din, A., \& Ravigadevi, S. (2007). Molecular and Biochemical Approaches to Understanding Oil Palm-Ganoderma Interactions. Proceedings of Agriculture, Biotechnology and Sustainability Conference-Volume 1. pg. 228-247.

Nazeeb, M., Barakabah, S.S. and Loong, S.G. (2000). Potential of high intensity oil palm plantings in diseased environments. The Planter, 76: 699-710.

Sariah, M. and Zakaria, K. (2000). The use of soil amendments for the control of basal stem rot of oil palm seedlings. In: Flood, J., Bridge, P. D. and Holderness, M. (eds) (2000) Ganoderma disease of perennial crops. CABI Publishing, Wallingford.

Singh, H.P., Kaur, S., Batish, D.R., \& Kohli, R.K. (2009). Caffeic acid inhibits in vitro rooting in mung bean [Vigna radiata (L.) Wilczek] hypocotyls by inducing oxidative stress. Plant Growth Regulator, 57:21-30. 


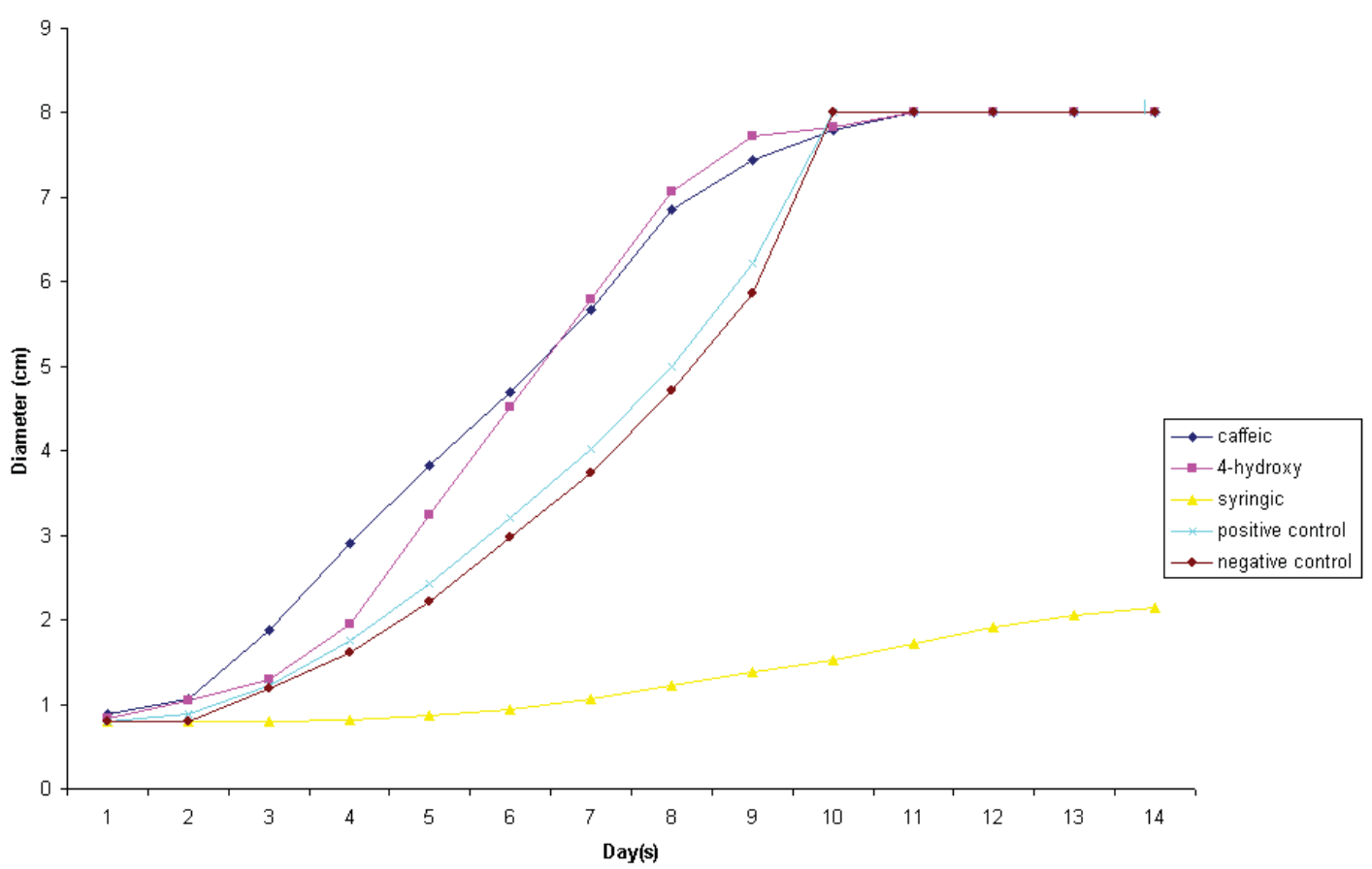

Figure 1. Radial growth of Ganoderma boninense on PDA ameliorated with $0.5 \mathrm{mg} / \mathrm{ml}$ of three different phenolics.

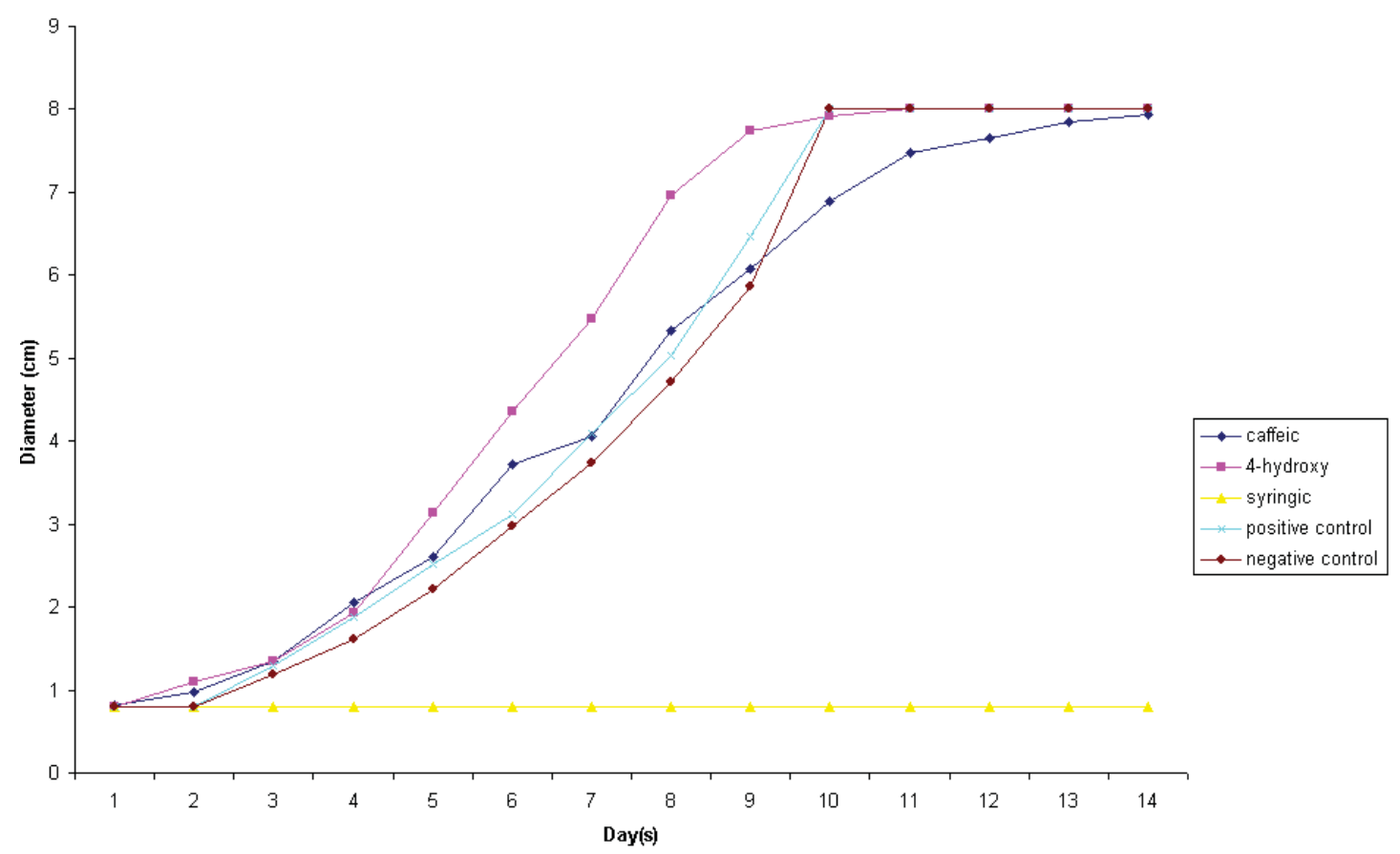

Figure 2. Radial growth of Ganoderma boninense on PDA ameliorated with $1.0 \mathrm{mg} / \mathrm{ml}$ of three different phenolics. 


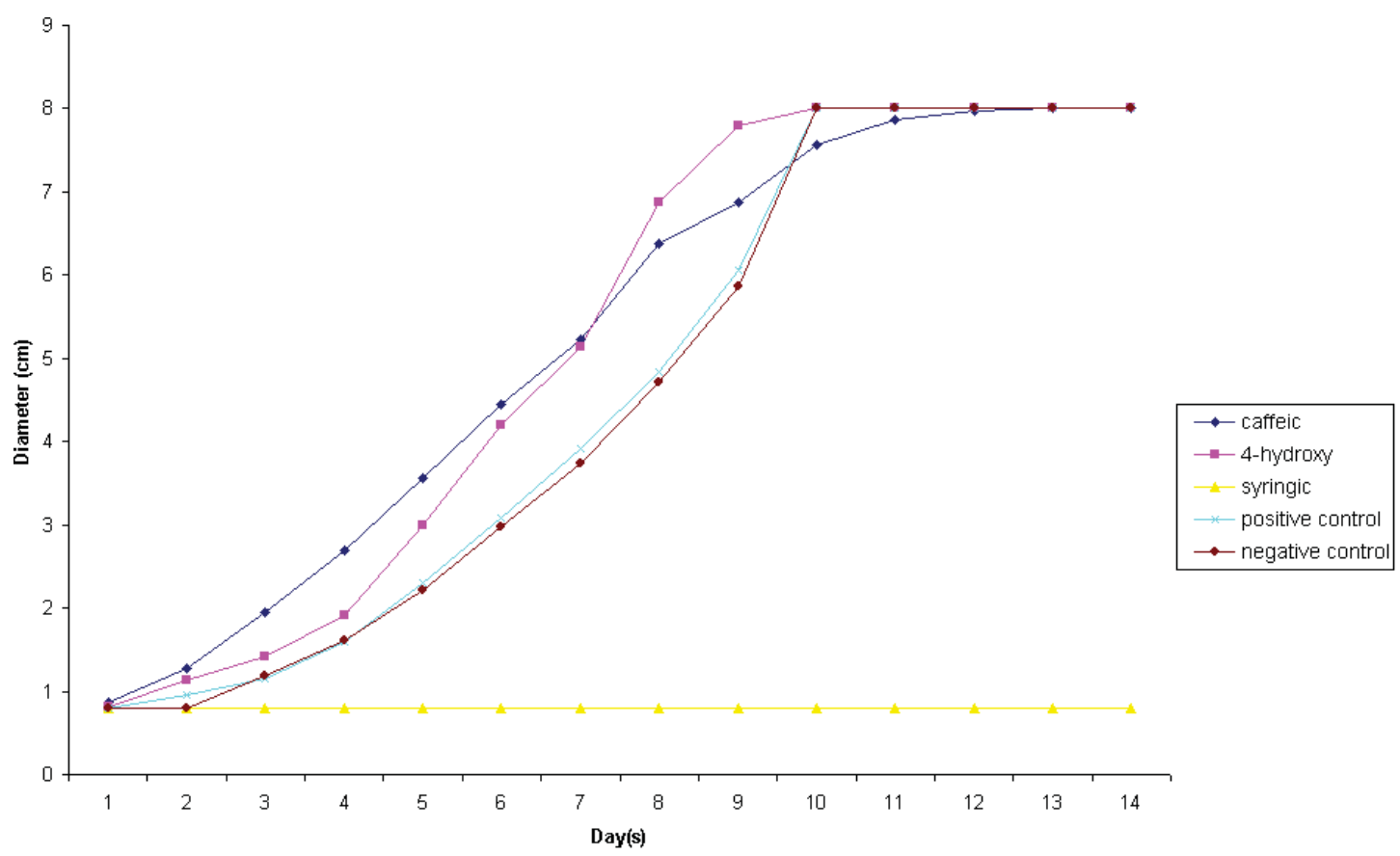

Figure 3. Radial growth of Ganoderma boninense on PDA ameliorated with $1.5 \mathrm{mg} / \mathrm{ml}$ of three different phenolics.

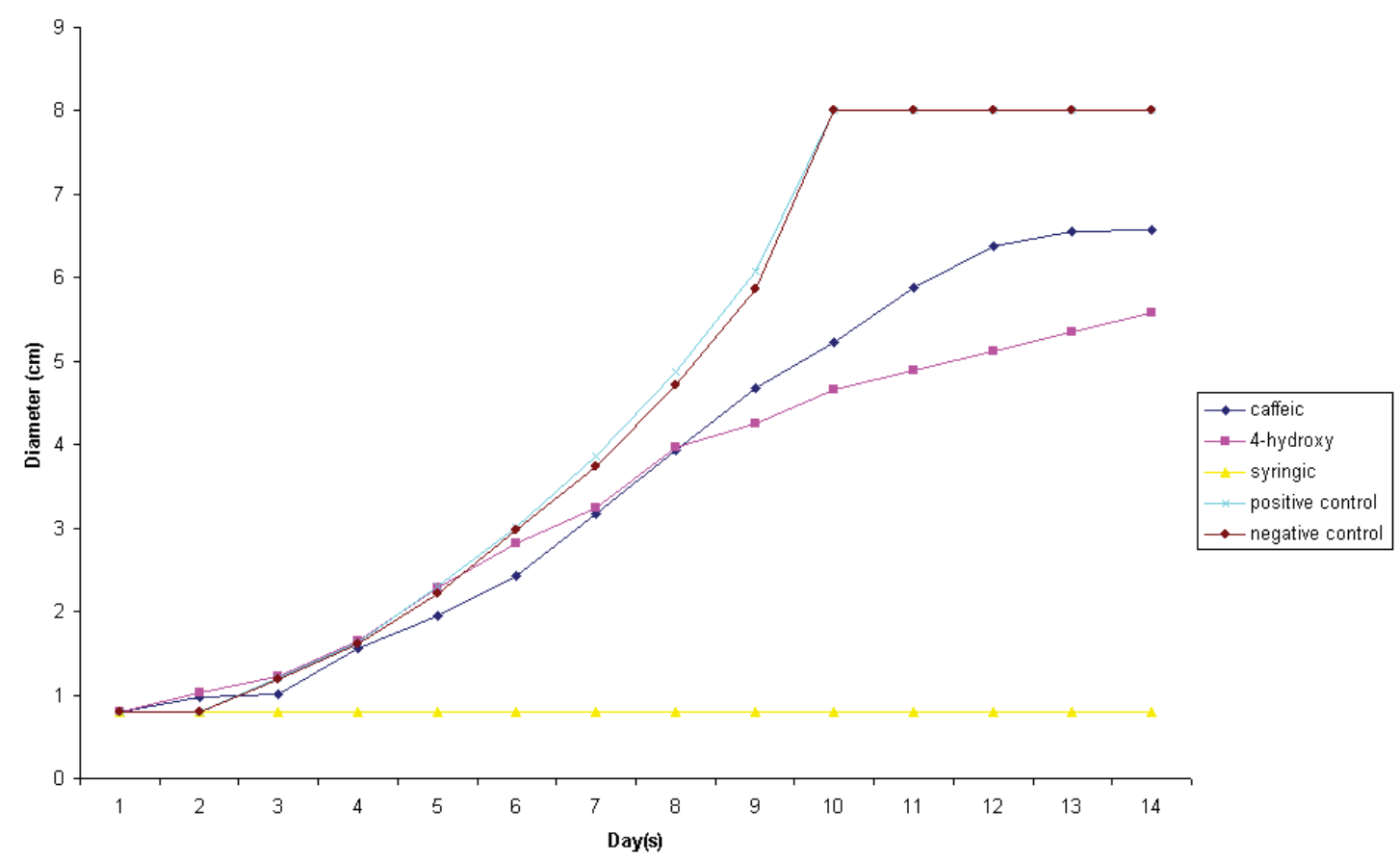

Figure 4. Radial growth of Ganoderma boninense on PDA ameliorated with $2.0 \mathrm{mg} / \mathrm{ml}$ of three different phenolics. 


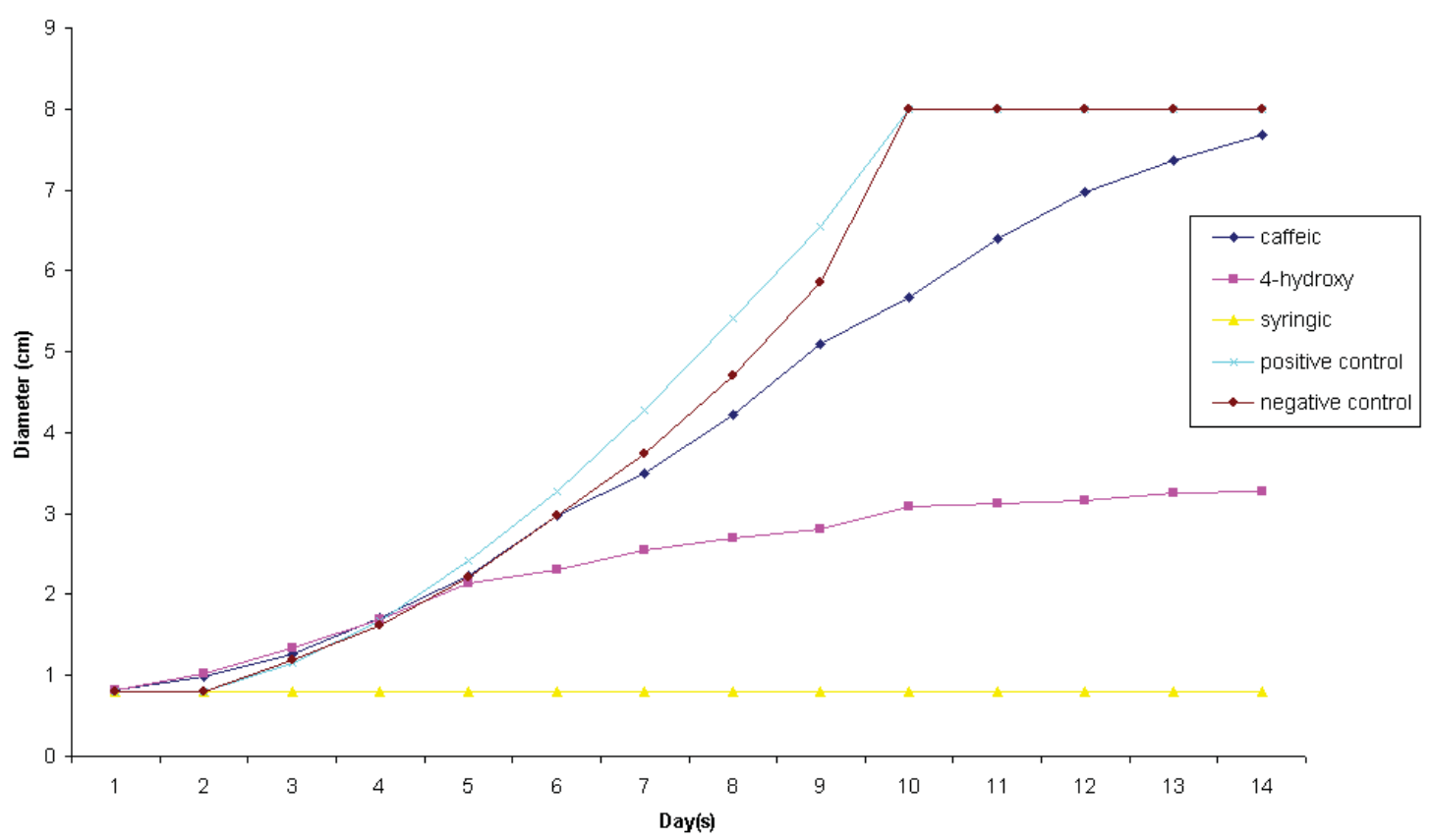

Figure 5. Radial growth of Ganoderma boninense on PDA ameliorated with $2.5 \mathrm{mg} / \mathrm{ml}$ of three different phenolics.

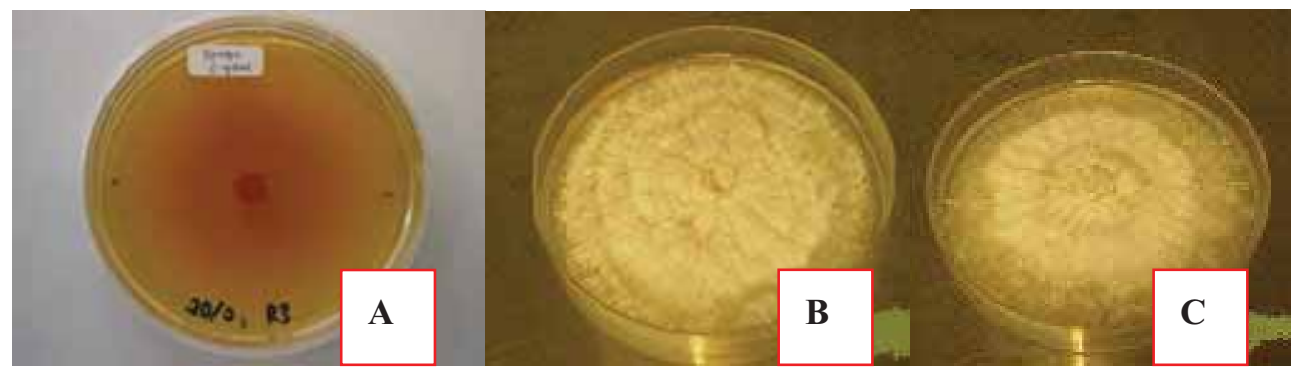

Figure 6. Ganoderma boninense failed to grow after incubated for 14 days in $1.0 \mathrm{mg} / \mathrm{ml}$ of syringic acid ameliorated in PDA and killed in this concentration (A). Continuous growth both in positive control (B) and negative control (C) 